- Eufrônio José d'Almeida Filho

- Elisa de Albuquerque Sampaio da Cruz - Marcos Hoette - Frederico Ruzany - Luana N eves Lopes Keen - Jocemir Ronaldo Lugon

\title{
Calcium acetate versus calcium carbonate in the control of hyperphosphatemia in hemodialysis patients
}

U niversidade Federal Fluminense, Niterói, and Francisco Santino Filho Kidney Foundation, Rio de Janero, B razil

\section{abstract}

CONTEXT: Hyperphosphatemia has an important role in the development of bone and mineral abnormalities in end-stage renal disease (ESRD).

OBJECTIVE: To compare the phosphorus binding power and the hypercalcemic effect of calcium acetate and calcium carbonate in hemodialysis patients.

TYPE OF STUDY: Crossover, randomized, double-blind study.

PLACE: A private hospital dialysis center.

PARTICIPANTS: Fifty-two patients who were undergoing regular hemodialysis three times a week $\left(\left[\mathrm{Ca}^{++}\right]\right.$dialysate $\left.=3.5 \mathrm{mEq} / \mathrm{L}\right)$.

PROCEDURES: Half of the patients were started on $5.6 \mathrm{~g} /$ day of calcium acetate and, after a 2 week washout period, received 6.2 $\mathrm{g} /$ day of calcium carbonate. The other half followed an inverse protocol.

MAIN MEASUREMENTS: C linical interviews were conducted 3 times a week to monitor for side effects. Determinations of serum urea, calcium, phosphorus, hematocrit, $\mathrm{Kt} / \mathrm{V}$ and blood gas analysis were obtained before and after each treatment.

RESULTS: Twenty-three patients completed the study. A significant increase in calcium plasma levels was only observed after treatment with calcium carbonate $[9.34 \mathrm{mg} / \mathrm{dl}$ (SD 0.91) vs. $9.91 \mathrm{mg} / \mathrm{dl}$ (SD $0.79), P<0.01]$. The drop in phosphorus levels was substantial and significant for both salts [5.64 mg/ dl (SD 1.54) vs. $4.60 \mathrm{mg} / \mathrm{dl}$ (SD 1.32 ), $P<0.01$ and $5.89 \mathrm{mg} / \mathrm{dl}$ (SD 1.71) vs. $4.56 \mathrm{mg} / \mathrm{dl}$ (SD 1.57), $P<0.01$, for calcium acetate and calcium carbonate respectively]. The percentage reduction in serum phosphorus (at the end of the study) per milliequivalent of salt administered per day tended to be higher with calcium acetate but statistical significance was not found.

CONCLUSION: Calcium acetate can be a good alternative to calcium carbonate in the handling of hyperphosphatemia in ESRD patients. W hen calcium a cetate is used, control of hyperphosphatemia can be achieved with a lower administration of calcium, perhaps with a lower risk of hypercalcemia.

KEY WORDS: Calcium Acetate. Calcium Carbonate. Hyperphosphatemia. Hypercalcemia. Hemodialysis.

\section{INTRODUCTION}

Hyperphosphatemia has an important role in the development of secondary hyperparathyroidism and bone disease in patients with end-stage renal disease (ESRD). ${ }^{1-8}$ Control of hyperphosphatemia can be achieved with the use of aluminum compounds that act as efficient phosphorus binders and reduce the intestinal absorption of phosphorus. However, especially due to neurologic and bone toxicity, aluminum compounds have been replaced by calcium salts. ${ }^{9-12}$ The most commonly used (calcium carbonate, $\mathrm{CaCO}_{3}$ ) is not the ideal binding agent, primarily because of its hypercalcemic effect. ${ }^{13-15}$ In this regard, calcium acetate $\left[\left(\mathrm{CH}_{3} \mathrm{COO}\right)_{2} \mathrm{Ca} . \mathrm{H}_{2} \mathrm{O}\right]$ has been reported by some authors to have at least a similar phosphorus binding efficiency, and a less pronounced hypercalcemic effect $^{16-19}$ but this subject is still a matter of controversy. ${ }^{20-24}$ This study was designed to compare the efficiency, tolerance and side effects of these salts.

\section{METHODS}

Fifty-two stable ESRD patients undergoing regular hemodialysis in a hospital dialysis center for 47 months (SD 26) entered the study. They were maintained on their usual diet. Parathyroidectomized patients were not included. Dialysis was performed three times a week utilizing a cuprophane membrane with a surface area of between 1.0 and $1.5 \mathrm{~m}^{2}$. Dialysis sessions were accomplished using non-proportional mixture machines without an ultrafiltration control device (Baxter Inc., McGraw Park, IL 60085, 
USA), blood flow of $300 \mathrm{ml} / \mathrm{min}$, and bicarbonate buffered dialysate $([\mathrm{Ca}]=3.5 \mathrm{mEq} / \mathrm{L})$ at $500 \mathrm{ml} / \mathrm{min}$. A de-ionizer was used to provide water treatment. Dialyzers were manually reprocessed with formaldehyde as the sterilizing agent and were discarded if the internal volume of the hollow fibers decreased

Table 1. General features of the patients

\begin{tabular}{lcc}
\hline & $\begin{array}{c}\text { All } \\
(\mathbf{n = 5 2 )}\end{array}$ & $\begin{array}{c}\text { Accepted for } \\
\text { analysis (n=23) }\end{array}$ \\
Age, years. & $46($ SD 14) & 50 (SD 14) \\
Sex (M / F) & $26 / 26$ & $13 / 10$ Race \\
(W / B) & $23 / 29$ & $12 / 11$ Time \\
on dialysis, months. & 47 (SD 26) & 50 (SD 25) \\
P intake, mg/ day. ${ }^{b}$ & 757 (SD 248) & 795 (SD 263) \\
Ca intake, mg/ day. & 329 (SD 209) & 385 (SD 245) \\
Primary Renal Disease & & \\
$\quad$ Chronic glomerulonephritis & 16 & 6 \\
M alignant nephrosclerosis & 19 & 8 \\
Polycystic disease & 3 & 2 \\
Diabetic nephropathy & 3 & 6 \\
Other & 11 & 1 \\
\hline a Mean and standard deviation; ${ }^{b}$ As obtained by nutritional inquiry.
\end{tabular}

Table 2. Total number of patients starting and finishing each treatment

\begin{tabular}{lcc}
\hline & \multicolumn{2}{c}{ N umber of patients } \\
\cline { 2 - 3 } & Acetate & Carbonate \\
\hline Starting & 50 & 51 \\
Finishing & 31 & 33 \\
Excluded & 19 & 18 \\
\hline
\end{tabular}

Table 3. Reasons for exclusion

\begin{tabular}{lcc}
\hline & Acetate & Carbonate \\
\hline Voluntary dropout due to side effects & 03 & - \\
Irregular use due to side effects & 04 & 03 \\
Inadequate adherence not declared & 08 & 12 \\
A bsent for the blood collection & 03 & - \\
Clinical problems unrelated to drug use & 01 & 03 \\
Total & $\mathbf{1 9}$ & $\mathbf{1 8}$ \\
\hline
\end{tabular}

Table 4. Complaints along drug treatment

\begin{tabular}{lcc}
\hline Symptoms & Acetate & Carbonate \\
\hline Pruritus & 02 & 03 \\
A norexia & 04 & 02 \\
N ausea & 03 & - \\
Constipation & 04 & 04 \\
Vomiting & 02 & - \\
Epigastralgia & 05 & 04 \\
Diarrhea & 01 & 01 \\
M alaise & 05 & - \\
Xerostomia & 01 & 05 \\
Plenitude & 05 & 03 \\
Dropout or irregular use due to side effects & 07 & 03 \\
\hline Total & $\mathbf{3 8}$ & $\mathbf{2 5}$ \\
\hline
\end{tabular}

more than $20 \%$. Other cleaning agents were not used.

The daily intake of calcium and phosphorus was quantified through nutritional inquiry. The majority of the patients used calcium carbonate and/or $1,25[\mathrm{OH}]_{2} \mathrm{D}_{3}$ in variable doses, which were withdrawn for a period of two weeks before the beginning of the study. All other types of medications, such as antihypertensive agents, vitamins, folic acid and erythropoietin were maintained.

The study was conducted in a crossover, randomized, double blind manner. Half of the patients were initiated on $5.6 \mathrm{~g} /$ day of calcium acetate $(0.069$ equivalents of the salt, corresponding to $1.4 \mathrm{~g} /$ day of elemental calcium) (Maia de Almeida Indústria e Comércio, RJ, Brazil) for 4 weeks followed by a washout period of two weeks. After this period they received $6.2 \mathrm{~g} /$ day of calcium carbonate $(0.124$ equivalents of the salt, corresponding to $2.5 \mathrm{~g} /$ day of elemental calcium) (Maia de Almeida Indústria e Comércio, RJ, Brazil) for another four weeks. The remaining patients followed a similar protocol, but were initially given calcium carbonate and then calcium acetate. They were all instructed to take the medication during meals in such a way that the whole daily dose would be divided into three or four doses according to the dietary habit of the patient. Both preparations were tested "in vitro" for de-aggregation following the American Pharmacopoeia guidelines.

Clinical interviews were conducted three times a week to monitor for adverse effects. Serum urea, calcium, phosphorus, blood gas analysis, hematocrit and $\mathrm{Kt} / \mathrm{V}$ determinations were performed before and after each treatment. Kt/ $\mathrm{V}$ was calculated in a mid-week session from the formula $-\log N R$, in which $R$ is the ratio of post and pre-dialysis serum urea. Abdominal X-rays were taken of each patient to search for intact capsules on the fifth and tenth day of the treatment with each compound.

Statistical methods. Patients were included for data analysis if they utilized at least $2 / 3$ of the capsules received. Data was expressed as mean and standard deviation (SD) or median and range, depending upon the pattern of distribution. Frequencies were evaluated by the chi-squared test. Differences during the study were tested by "ANOVA" for repeated measurements, complemented by the Duncan test. Differences in percent variations of calcium and phosphorus between salts, and ratios of these percent variations, were evaluated by the non-parametric Sign Rank test. Values of $\mathrm{P}$ less than 0.05 were considered significant. 


\section{RESULTS}

Fifty-two subjects entered the study and twentythree were included in the data analysis. The general features of the patients are described in Table 1. Of the fifty-two subjects, twenty patients were using betablockers, three were being treated with human recombinant erythropoietin, two had had a bilateral nephrectomy and two had had past kidney transplants. Data regarding exclusion are depicted in Tables 2 and 3, and the side effects found for each drug are listed in Table 4.

Table 5 and Figure 1 summarize the laboratory findings from pre and post-treatment with calcium acetate and calcium carbonate. None of the preparations significantly altered the values of blood $\mathrm{pH}$ and bicarbonate.

A significant increase in calcium plasma levels was only observed after treatment with calcium [9.34 $\mathrm{mg} / \mathrm{dl}$ (SD 0.91) vs. $9.91 \mathrm{mg} / \mathrm{dl}$ (SD 0.79), $\mathrm{P}<0.01$ ]. The post-treatment plasma calcium levels between the two compounds, however, did not differ statistically. The drop in phosphorus levels was substantial and significant for both salts [5.64 mg/dl (SD $1.54)$ vs. $4.60 \mathrm{mg} / \mathrm{dl}$ (SD 1.32), $\mathrm{P}<0.01$ and $5.89 \mathrm{mg} /$ dl (SD 1.71) vs. $4.56 \mathrm{mg} / \mathrm{dl}$ (SD 1.57), $\mathrm{P}<0.01$, for acetate and carbonate, respectively). Again, posttreatment $P$ levels between the two salts were not different.

There were no significant changes in Kt/V throughout the study. The percent variations in serum levels of calcium and phosphorus after treatment with each drug are shown in Figure 1. Analysis of the top and bottom panels suggests that more phosphorus was bound by each equivalent of calcium acetate in comparison to calcium carbonate but statistical significance was not found.

Comparisons of the hyperphosphatemic and hypercalcemic properties of the two salts are depicted in Figure 2. Calcium acetate was 4.4 times more hyperphosphatemic than hypercalcemic; the corresponding calcium carbonate value of this variable was 3.7 but, again, the differences were not statistically significant.

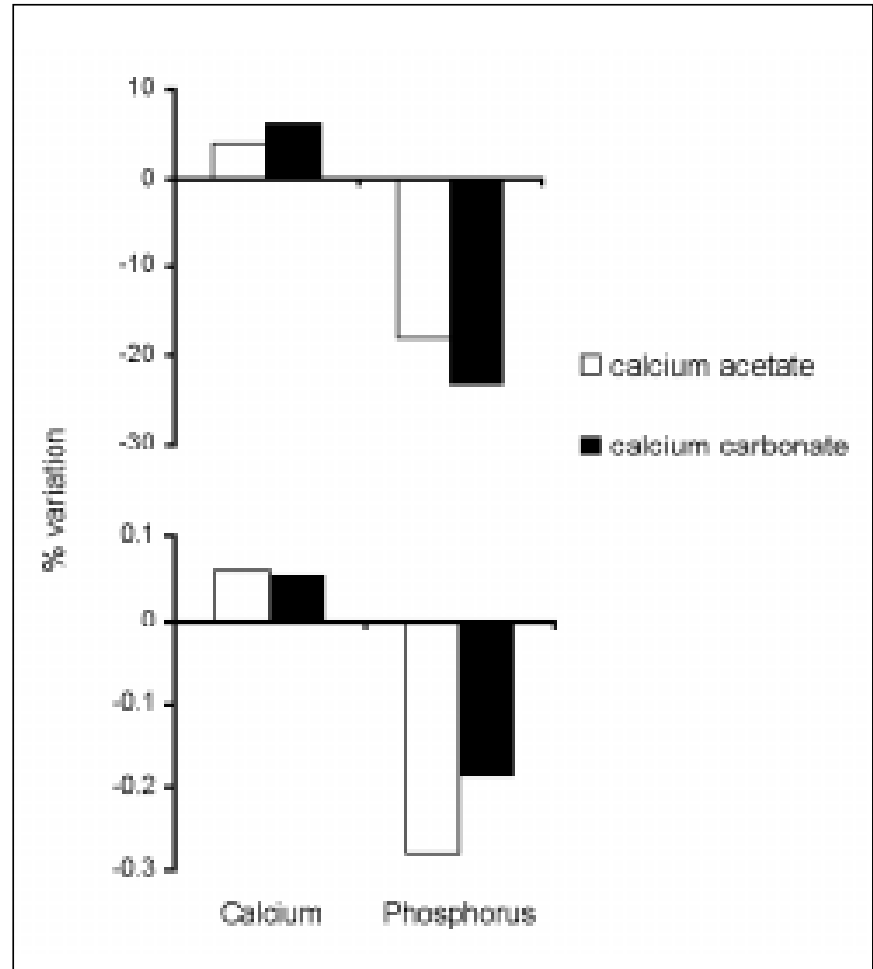

Figure 1. Mean values of the serum level variation in calcium and phosphorus. Top panel: percent variation. Bottom panel: percent variation by milliequivalent of salt administered per day (no significance was found between salts under any circumstance).

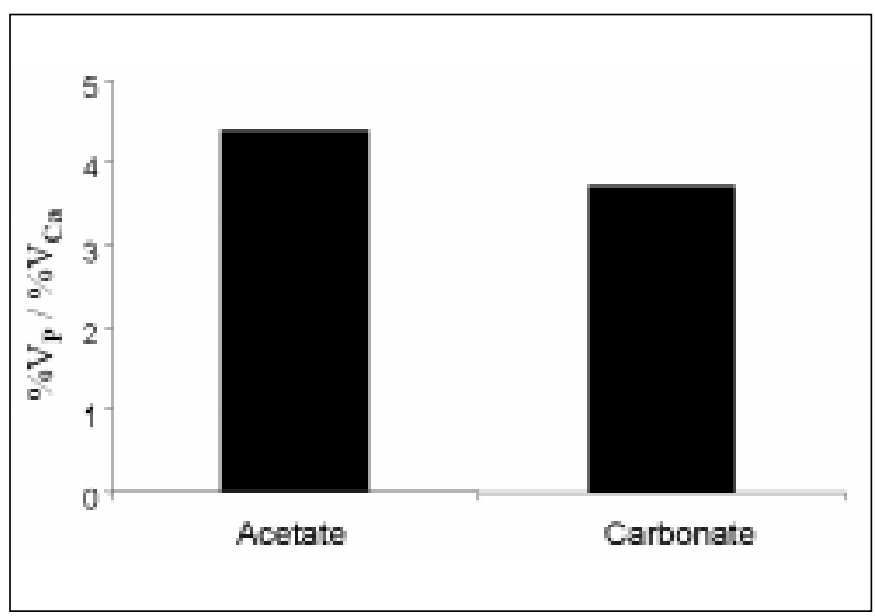

Figure 2. Ratios of mean percent variations $(\% \mathrm{~V})$ in plasma levels of $\mathrm{P}$ and $\mathrm{Ca}$ at the end of the treatment period for the 2 salts.

Table 5. Laboratory find ings before and after treatment

\begin{tabular}{|c|c|c|c|c|}
\hline \multirow[b]{2}{*}{ Laboratory findings } & \multicolumn{2}{|c|}{ Acetate } & \multicolumn{2}{|c|}{ Carbonate } \\
\hline & Before & After & Before & After \\
\hline $\mathrm{pH}$ & $7.31(0.05)^{\mathrm{a}}$ & $7.33(0.04)$ & $7.30(0.06)$ & $7.32(0.05)$ \\
\hline $\mathrm{HCO}_{3}-(\mathrm{mEq} / \mathrm{L})$ & $17.3(2.3)$ & $18.6(2.0)$ & $18.6(2.2)$ & $18.9(2.2)$ \\
\hline $\mathrm{Ca}(\mathrm{mg} / \mathrm{dl})$ & $9.34(0.70)$ & $9.73(0.62)$ & $9.34(0.91)$ & $9.91(0.79)^{*}$ \\
\hline$P(\mathrm{mg} / \mathrm{dl})$ & $5.64(1.54)$ & $4.60(1.32)^{*}$ & $5.89(1.71)$ & $4.56(1.57)^{*}$ \\
\hline $\mathrm{Kt} / \mathrm{V}$ & $1.03(0.24)$ & $1.15(0.17)$ & $1.04(0.23)$ & $1.15(0.19)$ \\
\hline
\end{tabular}

a $M$ ean and standard deviation, $* P<0.02$ vs. pretreatment values. 


\section{DISCUSSION}

Hyperphosphatemia has been implicated in different manners in the genesis of parathyroid hyperfunction, a condition that has been associated with high turnover bone disease. It can also contribute to the mineral alterations in ESRD by inducing bone resistance to parathyroid hormone ${ }^{25,26}$ and precipitation of metastatic vascular and non-vascular ${ }^{27-30}$ calcifications. To reinforce all these reasons in favor of there being an adequate control of serum phosphate levels in uremia, high calcium-phosphorus product has recently been associated to lower survival on dialysis. ${ }^{31}$

In the present study, calcium carbonate and calcium acetate were compared regarding their phosphorus binding properties, hypercalcemic effects, and tolerance. The protocol was designed in such a way that comparable doses (in grams) of each salt were given during each phase of the study. This strategy allowed intake of the same number of identical capsules in both phases, affirming the double-blind nature of the study. In this context, the daily amount of calcium prescribed was always lower with calcium acetate.

The study dropout ratio for each compound was high, but not different statistically (38\% for calcium acetate and $35 \%$ for calcium carbonate). Tolerance and side effects were also comparable, although upper gastrointestinal symptoms tended to be more frequent with calcium acetate. A detailed examination of the different reasons for exclusion did not show statistically significant differences. Therefore, the acceptance of the compounds was similar. Neither acetate nor carbonate induced significant changes in blood $\mathrm{pH}$ and bicarbonate. Relevant alterations were restricted to calcium and phosphate plasma levels. Consistent with studies reporting a less hypercalcemic effect for cal cium acetate, ${ }^{16,24,32,33}$ a statistically significant rise in calcium levels (7\%) was only found with carbonate. This finding could simply be accounted for by the lower amount of elemental calcium given during acetate treatment (by study design). In support of this hypothesis, the hypercalcemic effects of the drugs became strikingly similar when variations in serum calcium were normalized according to the number of equivalents administered. Numerous studies have been made that refute the existence of a lesser hypercalcemic effect with calcium acetate in comparison to calcium carbonate. ${ }^{20-23}$ Intriguingly, the only prospective double-blind crossover comparison in the literature favors a high frequency of hypercalcemia with calcium acetate. ${ }^{23}$ However, there were relevant differences in study design that may account for the discrepancy between the findings. At first, the administered dose of salts in that study was matched to contain the same amount of elemental calcium; and secondly, binders were given consecutively without a washout period.

The reductions in serum phosphorus were significant for both treatments (18.4\% for acetate and $22.6 \%$ for carbonate). There was no significant difference between the post-treatment plasma values of phosphorus with the two compounds. Thus, a similar phosphorus binding power was found for the salts, despite the lower number of equivalents of acetate administered.

Comparison of the hyperphosphatemic and hypercalcemic capacity ratios of the two salts did not show a statistically significant difference but tended to be slightly higher for acetate: the phosphorus binding power of acetate was about 4.4 times greater than its hypercal cemic effect while, for carbonate, the value of this variable was 3.7.

The present observations, in spite of being partially derived from a mathematical exercise, are consistent with data from the literature ${ }^{13,15,34-37}$ and suggest that a trial of calcium acetate may be worthwhile in patients undergoing treatment with calcium carbonate who have hypercalcemic episodes or are more prone to such complication.

\section{CONCLUSION}

Calcium acetate is an acceptable alternative to calcium carbonate in the management of hyperphosphatemia in ESRD patients. When acetate is used, control of hyperphosphatemia can be achieved with considerably lower administration of cal cium, perhaps with a lower risk of hypercalcemia. 


\section{REFERENCES}

1. Brent GA, LleBoff MS, Seely EW, Conlin PR, Brown EM. Relationship between the concentration rate of change of calcium and serum intact parathyroid hormone levels in normal humans. J Clin Endocrinol Metab 1988;67:944-50.

2. Conlin PR, Fajtova VT, Mortensen RM, LleBoff MS, Brown EM. Hysteresis in the relationship between serum ionized calcium and intact parathyroid hormone during recovery from induced hyper and hypocalcemia in normal humans. J Clin Endocrinol Metab 1989;320:1140-1.

3. Sherwood Lm, Mayer GP, Ramberg CF, Kronfeld DS, Aubach GD, Potts JT. Regulation of parathyroid hormone secretion: proportional control by calcium, lack of effect of phosphate. Endocrinology 1968;83:1043-51.

4. Reiss E, CanterburyJM, Bercovitz MA, Kaplan EL. The role of phosphate in the secretion of parathyroid hormone in man. J Clin Invest 1970;49:2146-9.

5. Lafflame GH, Jowsey J. Bone and soft tissue changes with oral phosphate supplements. J Clin Invest 1972;51:2834-40

6. Lopez-Hilker S, Dusso AS, Rapp NS, Martin KJ, Slatopolsky E. Phosphorus restriction reverses hyperparathyroidism in uremia independent of changes in calcium and calcitriol. Am J Physiol 1990;259:432-7

7. Lucas PA, Brown RC, Woodhead JS, Coles GA. 1-25 dihydroxycholecalciferol and parathyroid hormone in advanced chronic renal failure: effects of simultaneous protein and phosphorus restriction. Clin Nephrol 1986;25:7-10.

8. Portale $A A$, Both $B E$, Halloran BP, Morris Jr RC. Effect of dietary phosphorus on circulating concentrations of 1-25 dihydroxyvitamin $D$ and immunoreactive parathyroid hormone in children with moderate renal insufficiency. J Clin Invest 1984;73:1580-9.

9. Alfrey $A C$. Aluminum intoxication. New Engl J Med 1984;310:1113-4.

10. Larson EA, Ash SR, White JL, Hem SL. Phosphate binding gels: balancing phosphate absorption and aluminum toxicity. Kidney Int 1986;29:1131-5.

11. Weberg R, Berstad A. Gastrointestinal absorption of aluminum from single doses of aluminum containing antacids in man. Euro J Clin Invest 1986;16:428-32.

12. Kirschbaum BB, Schoolwerth AC. Acute aluminum toxicity associated with oral citrate and aluminum containing antacids. Am J Med Sci 1989;297:9-11.

13. Slatpolsky E, Weerts C, Lopez-Hilker S, et al. Calcium carbonate as a phosphate binder in patients with chronic renal failure undergoing dialysis. New Engl J Med 1986;315:157-61.

14. Ramirez JA, Emmett M, White MG, et al. The absorption of dietary phosphorus and calcium in hemodialysis patients. Kidney Int 1988;30:753-9.

15. Meric F, Yap P, Bia MJ. Etiology of hypercalcemia in hemodialysis patients on calcium carbonate therapy. Am J Kidney Dis 1990;16:459-64.

16. Mai ML, Emmett M, Sheikh MS, Santa Ana CA, Schiller L, Fordtran JS. Calcium acetate, an effective phosphorus binder in patients with renal failure. Kidney Int 1989;36:690-5.

17. Papadakis J, Patrickarea A, Barbatsi A, et al. Calcium acetate: a suitable alternative to calcium carbonate as phosphate binder (abstract). Vienna, Austria: Proceedings of the XXVII Congress of the European Dialysis and Transplant Association/European Renal Association; 1990:279.

18. Schiller LR, Santa Ana CA, Mudassir BS, Sheikh MS, Emmett M, Fordtran JS. Effect of time of administration of calcium acetate on phosphorus binding time. New Engl J Med 1989;320:1110-3.

19. Biagini M, Bargana R, Sicoli R, Friggi A, Malaguti M. Calcium acetate as a phosphate binder: clinical experience in patients on regular dialysis treatment (abstract). Vienna, Austria: Proceedings of the XVII Congress of the European Dialysis and Transplant Association/ European Renal Association; 1990:270.

20. Ben Hamida F, El Esper I, Compagnon M, Monière P, Fournier A. Long term crossover comparison of calcium carbonate as phosphate binder. Nephron 1993;63:258-62

21. Almirall J, Veciana L, Llibre J. Calcium acetate versus calcium carbonate for the control of serum phosphorus in hemodialysis patients. Am J Nephrol 1994;14:192-6

22. Monière $P$, Djerad $M$, Boudailliez $B$, et al. Control of predialytic hyperphosphatemia by oral calcium acetate and calcium carbonate. Nephron 1992;60:6-11.

23. Ring I, Nielsen C, Andersen SP, Behrensss JK, Sodemann B, Korneup $\mathrm{HJ}$. Calcium acetate versus calcium carbonate as phosphorus binders in patients on chronic hemodialysis: a controlled study. Nephrol Dial Transplant 1993;8:341-6.

24. Wallot M, Bonzel K, Winter A, Georger B, Lettgen B, Bald M. Calcium acetate versus calcium carbonate as oral phosphate binder in pediatric and adolescent hemodialysis patients. Pediatr Nephrol 1996;10:625-30.

25. Massry SG, Coburn JW, Lee DB, Jowsey J, Kleeman CR. Skeletal resistance to parathyroid hormone in renal failure. Ann Intern Med 1973;78:357-64.

26. Galceran T, Martin KJ, Morrissey JJ, Slatopolsky E. The role of $1,25(\mathrm{OH})_{2} \mathrm{D}_{3}$ on the pathogenesis of skeletal resistance to parathyroid hormone in chronic renal failure. Kidney Int 1987;32:801-7.

27. Arora KK, Lacey JP, Schacht RA, Martin DG, Gutch CF. Calcific cardiomyopathy in advanced renal failure. Arch Inter Med 1975;135:603-5.

28. Gipstein RM, Kaplan EL, Katz Al. Hypercalcemia after oral calcium carbonate therapy in patients on chronic hemodialysis. Lancet 1973;9:1271-4.

29. Parfitt AM, Massry SG, Winfield AC, De PalmaJR, Gordon A. Disordered calcium and phosphorus metabolism during maintenance hemodialysis. Am J Med 1971;51:319-30.

30. Milliner DS, Zinsmeister AR, Lieberman E, Landing B. Soft tissue calcification in pediatric patients with end-stage renal disease. Kidney Int 1990;38:931-6.

31. Block GA, Shearon TEH, Levin NW, Port FK. Association of serum phosphorus and calcium $x$ phosphorus product with mortality risk in chronic hemodialysis patients: a national study. Am J Kid Dis 1998;31:607-17.

32. Sheikh MS, Maguire JA, Emmet M, et al. Reduction of dietary phosphorus absorption by phosphorus binders. a theoretical, in vitro and in vivo study. J Clin Invest 1989;83:66-73.

33. Caravaca F, Santos I, Robles R, et al. Calcium acetate versus calcium carbonate as phosphate binders in hemodialysis patients (abstract). Vienna, Austria: Proceedings of the XXVII Congress of the European Dialysis and Transplant Association/European Renal Association; 1990:270..

34. Andress DL, Norris KC, Coburn JW, Slatopolsky EA, Sherrard DJ. Intravenous calcitriol in the treatment of refractory osteitis fibrosa of chronic renal failure. New Engl J Med 1989;321:274-9.

35. Delmez JA, Tindira C, Grooms P, Dusso A, Windus BW, Slatopolsky EA. Parathyroid hormone suppression by intravenous 1,25dihydroxyvitamin D: A role for increased sensitivity to calcium. J Clin 
Invest 1989;83:1349-55.

36. Gallieni M, Brancaccio D, Padovesi $P$, et al. Low-dose intravenous calcitriol treatment of secondary hyperparathyroidism in hemodialysis patients. Kidney Int 1992;42:1191-8.
37. Muramoto H, Haruki K, Yoshimura A, Mimo N, Oda K, Tofuko $Y$. Treatment of refractory hyperparathyroidism in patients on hemodialysis by intermittent oral administration of $1,25(\mathrm{OH})_{2}$ vitamin $D_{3}$. Nephron 1991;58:288-94.

\section{esu mo}

CONTEXTO: A hiperfosfatemia tem um importante papel no desenvolvimento de anormalidades ósseas e minerais na insuficiência renal crônica terminal.

OBJ EIIVO: Comparar o acetato de cálcio com o carbonato de cálcio quanto às suas propriedades quelantes de fósforo e efeitos hipercalcêmicos.

TIPO DE ESTUDO: Ensaio clínico randomizado, cruzado, duplocego.

LOCAL: Centro de diálise hospitalar privado.

PARTICIPANTES: 52 pacientes em hemodiálise regular três vezes por semana ([Ca] dialisado $=3,5 \mathrm{mEq} / \mathrm{l})$.

PROCEDIMENTOS: Metade deles recebeu 5,6 $\mathrm{g} / \mathrm{dia}$ de acetato de cálcio e, após um período de "washout" de duas semanas, 6,2 $\mathrm{g} /$ dia de carbonato de cálcio. A outra metade seguiu protocolo inverso.

VARIÁVEIS ESTUDADAS: Foram conduzidas entrevistas clínicas para monitorar efeitos colaterais e obtidas a mostras sangüíneas para determinações da uréia sérica, cálcio, fósforo, hematócrito, Kt/ V e gasometria arterial, antes e após cada tratamento.

RESULTADOS: 33 pacientes completaram o estudo. Um aumento significativo nos níveis plasmáticos de cálcio só foi obtido após 0 tratamento com carbonato de cálcio $[9,34 \mathrm{mg} / \mathrm{dl}(\mathrm{SD} 0,91)$ vs. $9,91 \mathrm{mg} / \mathrm{dl}(\mathrm{SD} 0,79), \mathrm{P}<0,01)$. A queda nos níveis de fósforo foi substancial e significante para ambos os sais $[5,64 \mathrm{mg} / \mathrm{dl}(\mathrm{SD} 1,54)$ vs. 4,60 mg/ dl (SD 1,32), P < 0,01 e 5,89 mg/ dl (SD 1,71) vs. $4,56 \mathrm{mg} / \mathrm{dl}(\mathrm{SD} 1,57), \mathrm{P}<0,01$ para aceta to de cálcio e carbona to de cálcio, respectivamente). A o final do estudo, a redução percentual no fósforo sérico por equivalente de sal administra do por dia tendeu a ser maior com o a cetato de cálcio, mas uma diferença significante estatisticamente não foi encontrada.

CONCLUSÃO: 0 acetato de cálcio pode ser uma boa alternativa ao carbonato de cálcio no manejo da hiperfosfatemia em pacientes com insuficiência renal crônica terminal. Q uando o aceta to de cálcio é usado o controle da hiperfosfatemia pode ser alcançado com uma administração de cálcio menor, talvez acarretando um risco menor de hipercalcemia.

PALAVRAS-CHAVE: A cetato de Cálcio. Carbonato de Cálcio. Hiperfosfatemia. Hipercalcemia. Hemodiálise.

\section{publishing information}

Acknowledgements: Presented in part at the 24th Annual Meeting of the American Society of Nephrology, Baltimore, USA, November 1991.

Eufrônio José d'Almeida Filho, MD. Francisco Santino Filho Kidney Foundation, Rio de Janeiro, Brazil.

Elisa de Albuquerque Sampaio da Cruz, MD. Universidade Federal Fluminense, Niterói, RJ, Brazil.

Marcos Hoette, MD. Francisco Santino Filho Kidney Foundation, Rio de Janeiro, Brazil.

Frederico Ruzany, MD, PhD. Francisco Santino Filho Kidney Foundation, Rio de Janeiro, Brazil.

Luana Neves Lopes Keen, MD. Universidade Federal Fluminense, Niterói,

Rio de Janeiro, Brazil.

Jocemir Ronaldo Lugon, MD, PhD. Universidade Federal Fluminense, Niterói RJ, Brazil.

Sources of funding: Not declared

Conflict of interest: Not declared

Last received: 14 May 2000

Accepted: 20 June 2000

Address for correspondence:

Jocemir Ronaldo Lugon

Rua Haddock Lobo, 369/309 - Tijuca

Rio de Janeiro/RJ - Brasil - CEP 20260-131

e-mail: jocerl@ax.apc.org 